B

ульгарный псориаз и плоскокиеточный рак у больного АискоиАной красной во ччанкой

(С) Дубенский В.В., Некрасова Е.Г., Александрова О.А., Муравьева Е.С.

ФГБОУ ВО «Тверской государственный медицинский университет» Министерства здравоохранения России

170642, Россия, г. Тверь, ул. Советская, д. 4

Описан редкий случай сочетания вульгарного псориаза и плоскоклеточного рака полового члена у больного с дискоидной красной волчанкой. Приведены данные литературы по коморбидности дерматозов.

Ключевые слова: псориаз, дискоидная красная волчанка, плоскоклеточный рак, коморбидность.

Конфрликт интересов: авторы заявляют об отсутствии потенциального конфликта интересов, требующего раскрытия в данной статье.

Для цитирования: Дубенский В.В., Некрасова Е.Г., Александрова О.А., Муравьева Е.С. Вульгарный псориаз и плоскоклеточный рак у больного дискоидной красной волчанкой. Вестник дерматологии и венерологии. 2020;96(4):60-66. doi: https://doi.org/10.25208/vdv1120-2020-96-4-60-66 


\section{ulgar psoriasis and squamous cell carcinoma in a patient with} discoid lupus erythematosus

(C) Valery V. Dubensky, Elizaveta G. Nekrasova, Olga A. Alexandrova, Ekaterina S. Muravyova

Tver State Medical University

Sovetskaya str., 4, Tver, 170642, Russia

A rare case of a combination of vulgar psoriasis and squamous cell carcinoma of the penis in a patient with discoid lupus erythematosus is described. The literature data on the comorbidity of dermatoses are given.

Keywords: psoriasis, discoid lupus erythematosus, squamous cell carcinoma, comorbidity.

Conflict of interest: the authors state that there is no potential conflict of interest requiring disclosure in this article.

For citation: Dubensky VV, Nekrasova EG, Alexandrova OA, Muravyova ES. Vulgar psoriasis and squamous cell carcinoma in a patient with discoid lupus erythematosus. Vestnik Dermatologii i Venerologii. 2020;96(4):60-66. doi: https://doi.org/10.25208/vdv1120-2020-96-4-60-66 
В последние годы врачи различных специальностей достаточно часто используют понятие «коморбидность». Под коморбидностью понимают сочетание хронических заболеваний и синдромов, патогенетически взаимосвязанных друг с другом или совпадающих по времени у одного пациента [1-4]. Имеются указания на риск повышения коморбидности с возрастом: с 10\% у больных младше 19 лет и до $80 \%$ у лиц 80 лет и старше [5]. При этом учитывают, что коморбидность может оказывать влияние на течение, клинические проявления, возникновение осложнений, лечение и прогноз. При псориазе наиболее часто из коморбидных состояний рассматривают: ожирение, метаболический синдром, заболевания сердечно-сосудистой системы, сахарный диабет, депрессивные состояния и др. [2, 3, 6-8]. В литературе описаны сочетания псориаза с другими заболеваниями кожи: витилиго, вульгарной пузырчаткой, склеродермией, ихтиозом [9-12].

«Псориаз - системное иммуноассоциированное заболевание мультифракториальной природы с доминирующим значением в развитии генетических фракторов, характеризующееся ускоренной пролиферацией эпидермоцитов и нарушением их дифрференцировки, иммунными реакциями в дерме и синовиальных оболочках, дисбалансом между провоспалительными и противовоспалительными цитокинами, хемокинами...» [13]. Псориаз относится к числу наиболее распространенных заболеваний кожи и встречается у $1-2 \%$ населения развитых стран [5-7, 13]. Генетический компонент в развитии псориаза составляет 60-70\%, доля средовых факторов варьирует от 30 до 40\%. Полигенность при псориазе объясняет разнообразие симптомов, особенностей течения и осложнений этого хронического дерматоза [4, 5, 14].

Красная волчанка (КВ) - «мультифракториальное аутоиммунное воспалительное заболевание соединительной ткани, поражающее различные органы и системы и имеющее широкий спектр клинических проявлений» [13].

Заболеваемость кожными формами КВ составляет 3,0-4,2 случая на 100000 населения в год, при этом больные с дискоидной формой красной волчанки (ДКВ) составляют 70-80\%. Дебют заболевания чаще всего отмечается в возрасте от 20 до 40 лет, женщины болеют чаще мужчин $[13,17]$.

Исследования генетических механизмов указывают на перекрытие некоторых локусов, связанных с псориазом, и локусов других аутоиммунных или воспалительных заболеваний. Установлено, что вариант гена IL-23R оказался ассоциированным с псориазом, болезнью Крона, псориатическим артритом и болезнью Бехтерева - Штрюмпелля - Мари. Возможно, это объясняется активизацией при данных состояниях Th17 клеток через рецептор IL-23R [14-16]. Фактором риска при ревматоидном артрите, системной красной волчанке и сахарном диабете 1-го типа является ассоциированный с псориазом ген TNFAIP3 [5, 17].

Плоскоклеточный рак полового члена нередко возникает у необрезанных мужчин (или с фимозом в анамнезе), болевших в прошлом аногенитальными бородавками, эритроплазией Кейра, склероатрофическим лихеном [17]. Высокий риск развития плоскоклеточного рака полового члена и мошонки может быть обусловлен ПУВА терапией половых органов по поводу псориаза, возможно развитие на месте рубцовой атро- фрии при красной волчанке, в области посттравматических рубцов или длительно незаживающих ран (имеет худший прогноз и чаще рецидивирует после лечения) $[18,19]$.

В качестве иллюстрации представлен клинический случай развития распространенного вульгарного псориаза у больного хронической дискоидной красной волчанкой с последующим развитием у этого больного плоскоклеточного рака головки полового члена.

Больной Н., 57 лет, в декабре 2019 г. поступил в дерматовенерологическое отделение ГБУЗ Центра специализированных видов медицинской помощи им. В.П. Аваева (г. Тверь) с жалобами на высыпания на коже лица, сопровождающиеся незначительным зудом и жжением. Из анамнеза известно: болен с весны 1986 г., когда на коже щек появились розоватые пятна с шелушением, в дальнейшем они увеличились и распространились на кожу волосистой части головы, с выпадением волос в очагах. Больной обратился к дерматологу городской больницы г. Санкт-Петербурга, где был поставлен диагноз: дискоидная красная волчанка. Обследован ревматологом, системная красная волчанка исключена. Получал стационарное лечение 1 раз в 2-3 года до 2000 г. В связи со сменой места жительства в 2000 г. обратился к дерматологу ГБУЗ Центра специализированных видов медицинской помощи им. В.П. Аваева (г. Тверь) с жалобами на появление высыпаний на коже живота, верхних и нижних конечностей, был поставлен диагноз: вульгарный псориаз. Сопутствующий диагноз: дискоидная красная волчанка в стадии ремиссии. Получал стационарное лечение 1 раз в 2 года, последняя госпитализация в 2014 г. В период с 2015 до 2019 г. самостоятельно лечился топическими препаратами по поводу дискоидной волчанки и псориаза, от системной терапии отказался. В июле 2019 г. обратился к урологу по поводу врожденного фимоза полового члена, и больному в плановом порядке было проведено обрезание крайней плоти. На месте вмешательства, со слов больного, образовались незаживающие язвы. Гистологическое исследование не проводилось.

\section{Дерматологический статус}

Патологический процесс локализуется на коже головы, туловища, верхних и нижних конечностей, наружных гениталий. На коже головы - на волосистой части (лобная, височная и теменная области), ушных раковин (ладьевидные ямки), щек, подбородка, передней и боковых поверхностей шеи. Распространенность очагово-диссеминированная, на лице симметричная; воспаление неострое. Имеются очаги розово-красного цвета округлых, овальных и неправильных очертаний размером от двухрублевой монеты до $8 \times 12$ см. В очагах определяются зоны: эритемы, инфильтрации и фолликулярного гиперкератоза, рубцовой атрофии (рис. 1 a, б). Положительны симптомы “дамского каблучка», «апельсиновой корки», Бенье - Мещерского [13, 17]. На коже ладьевидных ямок ушных раковин - участки локальной атрофии. На волосистой части головы - участки стойкой рубцовой алопеции. На красной кайме верхней и нижней губы - проявления типичной формы хейлита (застойные участки кожи с плотными чешуйками и атрофией красной каймы), а на слизистой твердого неба и щек - типичной и экссудативно-гиперемической 


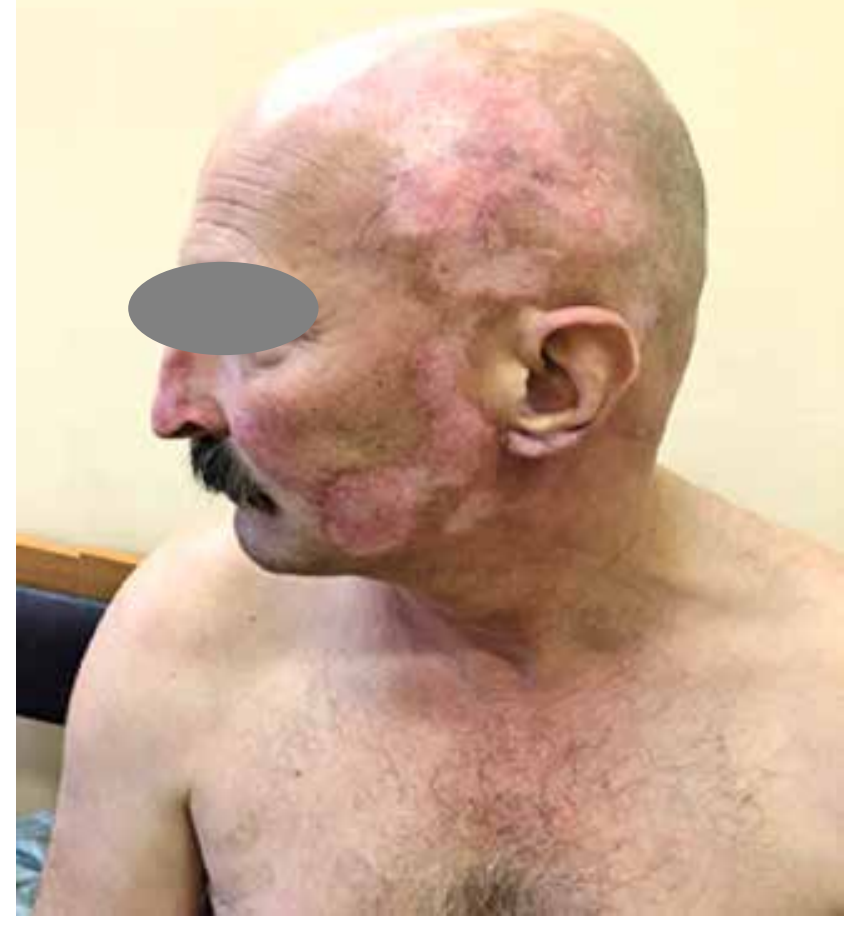

$a$

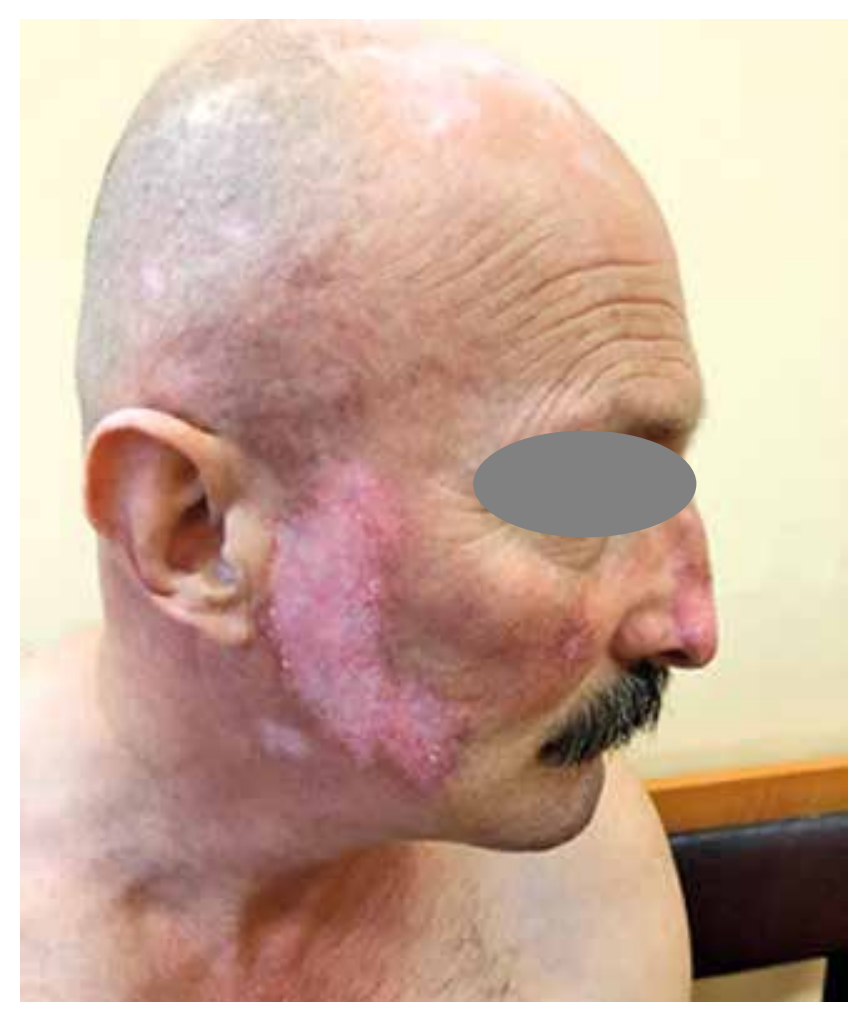

$\sigma$

Рис. 1. Больной Н., 57 лет, проявления ДКВ
Fig. 1. Patient N., 57 years old, manifestations of DLE

формы стоматита при ДКВ (рис. 2). На коже конечностей (разгибательные поверхности), плеч, предплечий, живота, ягодиц, нижних конечностей (кожа задней поверхности бедер, в области коленных суставов, передне-боковая поверхность голеней) имеется мономорфная папулезная сыпь ярко-розового цвета, элементы размером от лентикулярных до бляшек, покрытые мелко- и среднепластинчатыми чешуйками серебристо-белого цвета (рис. 3 а-в). Папулы склонны к периферическому росту и слиянию. Положительны феномены «стеаринового пятна», «терминальной пленки» и «кровяной росы». Отмечается изоморфная реакция на местах расчесов и инъекций. Также на коже голеней наблюдается поствоспалительная гипопигментация. Ногтевые пластины обеих кистей (I-V пальцы) с явлениями онихолизиса, дистрофических изменений (продольная исчерченность и симптом «наперстка») и «масляных пятен».

Наружные гениталии развиты правильно, органы мошонки без видимых патологических изменений, наружный листок крайней плоти удален, головка полового члена гиперемирована и отечна. Имеются язвенные дефекты (5) неправильных очертаний, с четкими границами, размером от $3 \times 4$ до $7 \times 8$ мм. Поверхность язв покрыта серозно-гнойными корками, легко кровоточит; по периферии дефектов - плотные чешуйко-корки (рис. 4). Отмечается болезненность в покое и при пальпации. Пальпаторно определяется незначительный болезненный инфильтрат в основании. Паховые лимфатические узлы не пальпируются.

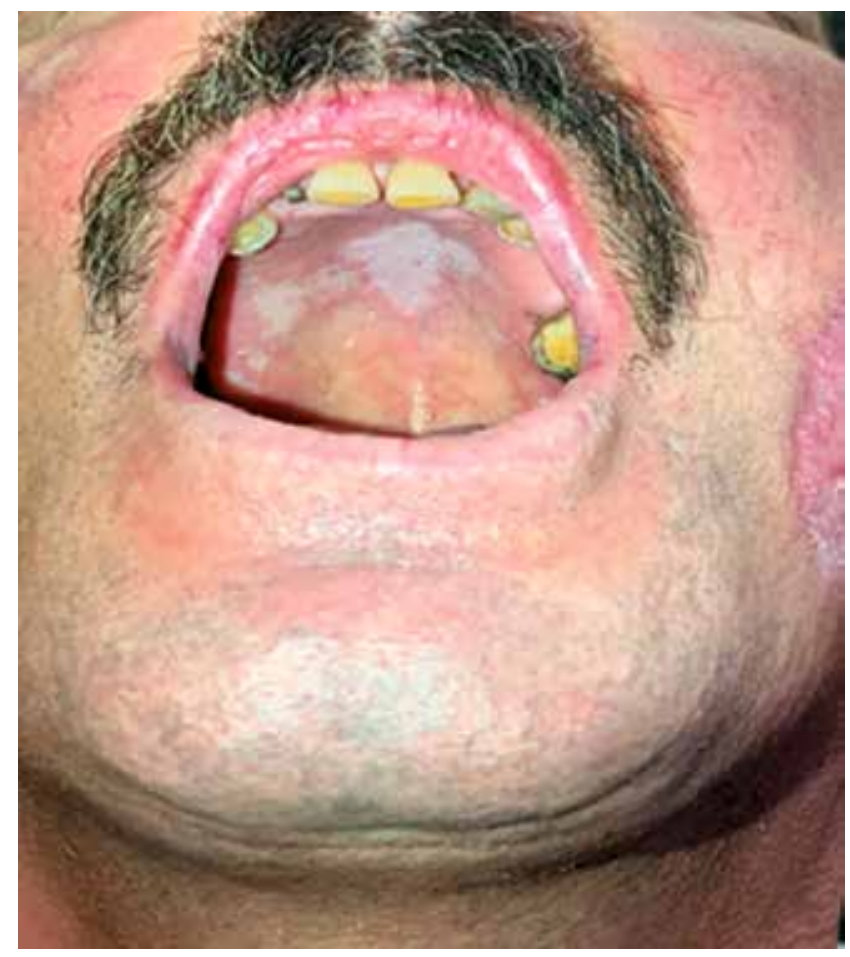

Рис. 2. Больной Н., 57 лет. Стоматит и хейлит при ДКВ

Fig. 2. Patient N., 57 years old. Stomatitis and cheilitis of DLE 


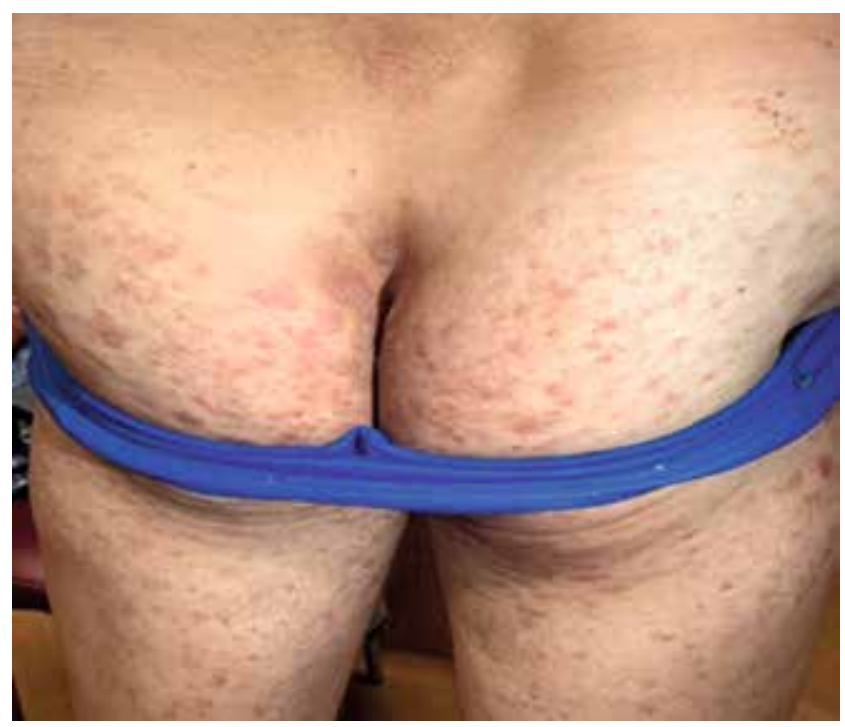

a

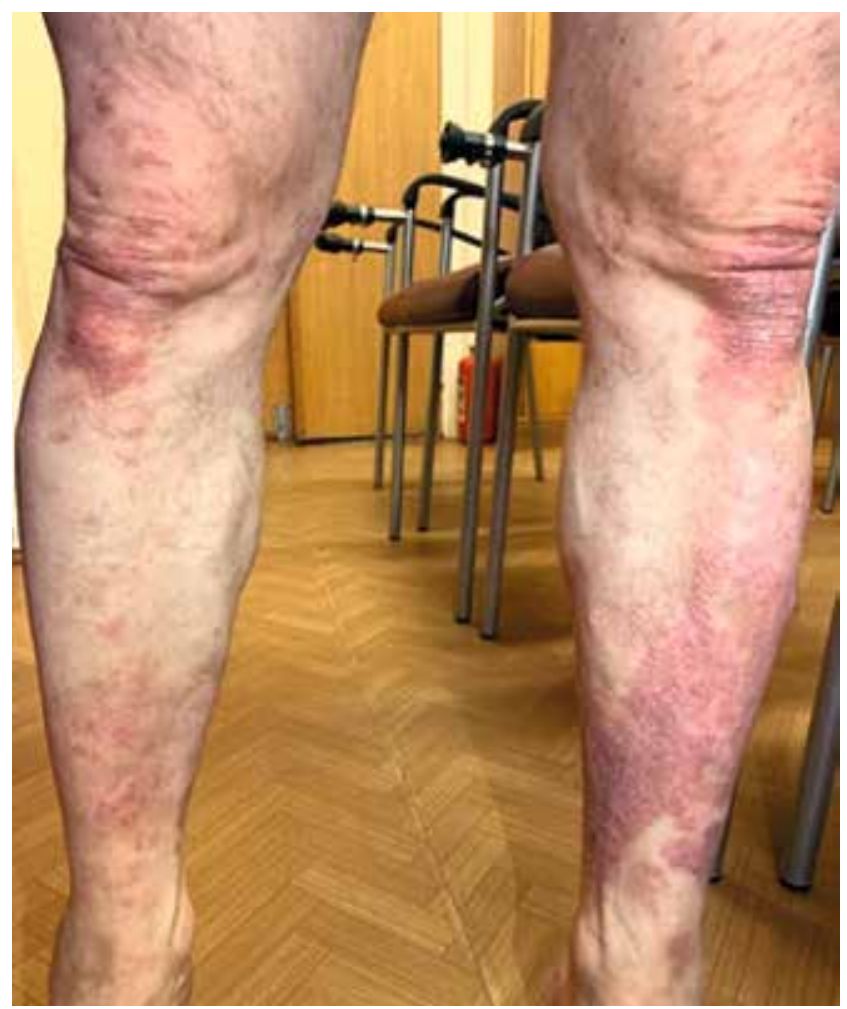

$\sigma$

Рис. 3. Больной Н., 57 лет: а — псориатические высыпания, б — псориатиче-
ские высыпания с гипопигментацией
Fig. 3. Patient N., 57 years old: a — psoriatic rashes, 6 - psoriatic rashes with
hypopigmentation

\section{Лабораторные исследования}

LE клетки не обнаружены. Клинический анализ крови: лейкоциты 4,52×10\%/л, эритроциты 4,66×1012/л, гемоглобин 152 г/л, тромбоциты 162×10\%/л, нейтрофилы 49,8\%, лимфроциты 35,2\%, моноциты 13,9\%, эозинофрилы 0,7\%, базофрилы 0,4\%, СОЭ 11 мм/ч. Биохимический анализ крови: АЛТ 23 Е/л, АСТ 18,9 Е/л, общий белок 75,6 г/л, билирубин общий 17,3 мкмоль/л, креа-

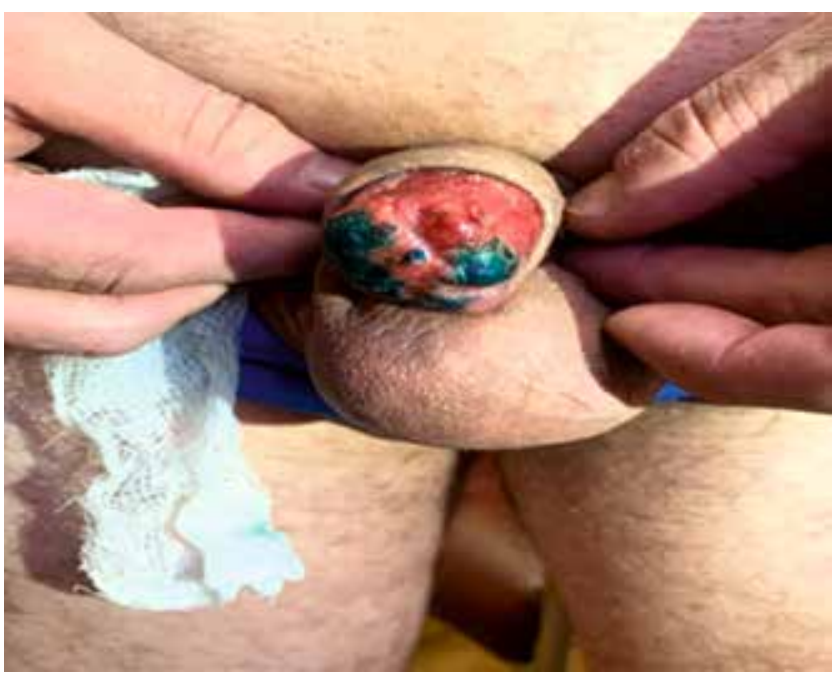

Рис. 4. Больной Н., 57 лет. Проявление плоскоклеточного рака полового члена Fig. 4. Patient N., 57 years old. Manifestation of squamous cell carcinoma of the penis

тинин 82 мкмоль/л, холестерин 5,44 ммоль/л, глюкоза 5,25 ммоль/л, щелочная фоссратаза 88 Е/л, триглицериды 1,63 ммоль/л, мочевина 5,3 ммоль/л. Общий анализ мочи, суточный белок в моче - в пределах нормы. Антитела к вирусному гепатиту C (HCVAg), австралийский антиген (HBsAg), MRP, РПГА - отрицательные, ИФА на АТ к ВИЧ - отрицательные.

Гистологическое исследование фрагмента очага на лице (один кусочек кожи). Определяются атрофия эпидермиса, гиперкератоз устьев и расширение волосяных фолликулов, незначительная вакуолизация клеток базального и шиповатого слоев. Граница между эпидермисом и дермой представлена в виде инфильтрированного слоя коллагеновых волокон. Отдельные перифолликулярные лимфоцитарные инфильтраты. Клеточные элементы: гистиоциты, фрибробласты, плазматические клетки. В гиподерме - периваскулярные инфильтраты и участки дезорганизации коллагена. Заключение: морфологические изменения соответствуют хронической фрорме красной волчанки.

Цитологическое исследование. В соскобе с головки полового члена (язвенной поверхности) обнаружены атипичные клетки эпителия. Рекомендовано гистологическое исследование.

23.01.2020 в Тверском областном онкологическом диспансере проведено хирургическое лечение с операционной биопсией: резекция полового члена под эндотрахеальным наркозом. Гистологическое исследование: изъязвленный умеренно дифференцированный плоскоклеточный ороговевающий рак головки полового члена с инфиильтрацией спонгиозного и кавернозных тел. Сосудистая периневральная инвазия (+). Граница резекции в пределах здоровых тканей. Заключение онкоконсилиума: рак полового члена, умеренно диффреренцированный рак T2NOMO, 2-я ст., 2-я клиническая группа.

Представленное клиническое наблюдение случая распространенного псориаза и плоскоклеточного рака полового члена у пациента с дискоидной красной волчанкой является иллюстрацией возможной 
коморбидности хронических дерматозов и онкологического заболевания. При этом верификация диагноза хронического дерматоза требует проведения дополнительных морфологических исследований и необходим междисциплинарный подход для диагностики онкологического заболевания. Сочетание хронических дерматозов является клиническим маркером глобальной аутоиммунной диссункции организма и может осложняться более частой онкологической патологи- ей по сравнению с общепопуляционными показателями. Коморбидность оказывает влияние на прогноз для жизни, увеличивает вероятность неблагоприятного исхода заболевания, определяет характер и тяжесть осложнений, затрудняет лечение. Наличие красной волчанки и плоскоклеточного рака затрудняет выбор системного лечения: больному противопоказана фототерапия, циклоспорин и некоторые биологические препараты.

\section{Литература/References}

1. Бакулев А.А., Штода Ю.М., Утц С.Р. К вопросу о коморбидности при псориазе. Саратовский научно-практический журнал. 2014;10(3):537-539. [Bakulev AA, Shtoda YuM, Utts SR To the question of comorbidity in psoriasis. Saratov Scientific and Practical Journal. 2014;10(3):537-539. (In Russ).]

2. Баткаева Н.В., Баткаев Э.А., Гитинова М.М., Маляренко Е.Н., Головинов А.И. Особенности заболеваний сердечно-сосудистой системы у больных тяжелыми и среднетяжелыми формами псориаза. Вестник РУДН. Медицина. 2018;22(1):92-101. [Batkaeva NV, Batkaev EA, Gitinova MM, Malyarenko EN, Golovinov Al. Features of diseases of the cardiovascular system in patients with severe and moderate forms of psoriasis. RUDN University Bulletin. Medicine. 2018;22(1):92-101 (In Russ).]

3. Батыршина С.В., Садыкова Ф.Г. Коморбидные состояния у больных псориазом. Практическая медицина. 2014;8(84):32-35. [Ваtyrshina SV, Sadykova FG. Comorbid conditions in patients with psoriasis. Practical medicine. 2014;8(84):32-35. (In Russ).]

4. Van Weel C, Schellevis FG. Comorbidity and guidelines: conflicting interests. Lancet. 2006;367:550-1.

5. Потекаев Н.Н., Круглова Л.С. Псориатическая болезнь. М.: Группа МДВ. 2014;27,97. [Potekaev NN, Kruglova LS. Psoriatic disease. M.: Group MDV, 2014;27,97. (In Russ).]

6. Мишина О.С. Коморбидный фон у людей с псориазом, проживающих в России. Вестник национального медико-хирургического Центра им. Н.И. Пирогова. 2014;9(4):61. [Mishina OS. Comorbid background in people with psoriasis living in Russia. Bulletin of the national medical and surgical Center N.I. Pirogova. 2014;9(4):61. (In Russ).]

7. Langan SM, Seminara NM, Shin DV, Troxel AB, Kimmel SE, Mehta NN, et al. Prevalence of metaboloc syndrom in patients with psoriasis: a population - based study in the United Kingdom. J. Invest Dermatol. 2012;132:556-62.

8. Yang YW, Keller JJ, Lin HC. Medical comorbidity associated with psoriasis in adults: a population- based study. Br. J. Dermatol. 2011;165:1037-43.

9. Гюльалиев Д.М. Сочетание склеродермии и псориаза. Клиническая дерматология и венерология. 2015;14(4):20-22. [Gyulaliev DM. Combination of scleroderma and psoriasis. Clinical dermatology and venereology. 2015;14(4):20-22. (In Russ).]

10. Дубенский В.В., Некрасова Е.Г., Муравьева Е.С., Александрова О.А., Гутянская Е.Ю. Псориаз у больной витилиго. Российский журнал кожных и венерических болезней. 2017;20(4):232-233. [Dubensky VV, Nekrasova EG, Muraveva ES, Alexandrova OA, Gutyanskaya EYu. Psoriasis in a vitiligo patient. Russian journal of skin and venereal diseases. 2017;20(4):232-233. (In Russ).]
11. Ковкова Г.Ю., Шабанова А.А., Матусевич С.Л., Бахлыкова Е.А. Сочетание псориаза и вульгарной пузырчатки у одного больного: клиническое наблюдение. Клиническая дерматология и венерология. 2018;1:34-38. [Kovkova GYu, Shabanova AA, Matusevich SL, Bakhlykova EA. Combination of psoriasis and vulgar pemphigus in one patient: clinical observation. Clinical dermatology and venereology. 2018;1:34-38. (In Russ).]

12. Тлиш М.М., Катханова О.А., Наатыж Ж.Ю., Поповская Е.Б., Сычева Н.Л. Псориаз у больного ихтиозом. Российский журнал кожных и венерических болезней. 2015;18(2):34-39. [Tlis MM, Kathanova OA, Naatig JY, Popovskaya EB, Sycheva NL. Psoriasis in a patient with ichthyosis. Russian journal of skin and venereal diseases. 2015;18(2):34-39. (In Russ).]

13. Российское общество дерматовенерологов и косметологов. Федеральные клинические рекомендации. Дерматовенерология 2015. М.: Деловой экспресс. 2016;395-405;415-470. [Russian society of dermatovenerologists and cosmetologists. Federal clinical guidelines. Dermatovenerology. 2016;395-405;415-470. (In Russ).]

14. Asumalahti $\mathrm{K}$, Laitinen $T$, Itkonen-Vatjus $\mathrm{R}$, et al. A candidate Gene for psoriasis near HLA-C, HCR (Pg8), is highly polymorphic with a diseaseassociated susceptibility allele. Hum Mol genet. 2000;9:1533-42.

15. Pirusian ES, Nikol'skaia TA, Abdeev RM, et al. Transcription factor AP-1 components as a psoriasis candidate genes. Mol Biol (Mosk). 2007 Nov Dec;41(6):1069-80.

16. Piruzian ES, Sobolev WV, Abdeev RM, et al. Study of the molecular mechanisms of pathogenesis of immunological inflammatory disorders using psoriasis as an example. Acta naturae. 2009;(3):139-50.

17. Голдсмит Лоуэлл А., Стивен И. Кац, Барбара А. Джилкрест, Эми С. Паллер, Дэвид Дж. Лесффель, Клаус Вольф. Дерматология Фицпатрика в клинической практике. Т. 2. Второе издание. 2016;1425-1437;21042122. [Goldsmith Lowell A, Stephen I Katz, Barbara A Gilcrest, Amy S Paller, David J Leffel, Klaus Wolf. Dermatology Fitzpatrick in clinical practice. V. 2. Second edition. 2016;1425-1437;2104-2122. (In Russ).]

18. Тополянская С.В. Плоскоклеточный рак кожи при системной красной волчанке: собственное наблюдение и обзор литературы. The Russian Archives of Internal Medicine. 2020;5:390-397. [Topolyanskaya SV. Squamous cell carcinoma of the skin in systemic lupus erythematosus: own observation and review of the literature. The Russian Archives of Internal Medicine. 2020;5:390-397. (In Russ).]

19. Плоскоклеточный рак кожи. Клинические рекомендации. 2020. [Электронный ресурc]. URL: https://oncology-association. ru/files/ new-clinical-guidelines/ploskokletochnyj_rak_kozhi.pdf. (дата обращения: 22.07.2020). [Squamous cell carcinoma of the skin. Clinical guidelines. 2020. [Electronic resource]. URL: https://oncology-association. ru/files/new clinical-guidelines/ploskokletochnyj_rak_kozhi.pdf. (date of the application: 22/07/2020) (In Russ).] 


\section{Информация об авторах}

Валерий Викторович Дубенский - д.м.н., профессор, заведующий кафедрой дерматовенерологии с курсом косметологии Тверского государственного медицинского университета Минздрава России

Елизавета Георгиевна Некрасова - к.м.н., доцент кафедры дерматовенерологии с курсом косметологии Тверского государственного медицинского университета Минздрава России; тел.: 8 (903) 804-07-70; e-mail: nekrasova-7@mail.ru

Ольга Александровна Александрова - ассистент кафедры дерматовенерологии с курсом косметологии Тверского государственного медицинского университета Минздрава России

Екатерина Сергеевна Муравьева - ассистент кафедры дерматовенерологии с курсом косметологии Тверского государственного медицинского университета Минздрава России

\section{Information about the authors}

Valery V. Dubensky - Dr. Sci. (Med.), Prof., head of the Department of Dermatovenerology with a course of cosmetology at Tver State Medical University, Ministry of Health of the Russian Federation

Elizaveta G. Nekrasova - Cand. Sci. (Med.), Assoc. Prof. of the Department of Dermatovenereology with a course of cosmetology at the Tver State Medical University, Ministry of Health of the Russian Federation; tel.: 8 (903) 804-07-70; e-mail: nekrasova-7@mail.ru

Olga A. Aleksandrova - Assistant of the Department of Dermatovenerology with a cosmetology course at Tver State Medical University, Ministry of Health of the Russian Federation

Ekaterina S. Muravyova - Assistant of the Department of Dermatovenerology with a cosmetology course at Tver State Medical University, Ministry of Health of the Russian Federation

Статья поступила в редакцию: 10.04.2020

Принята к публикации: 28.09.2020

Дата публикации: 12.11.2020
Submitted: 10.04 .2020

Accepted: 28.09.2020

Published: 12.11 .2020 